\title{
A coordination polymer with unusual structural features from imidazolylbutyric acid and titanium isopropoxide
}

\author{
Matthias Czakler • Michael Puchberger • \\ Christine Artner · Ulrich Schubert
}

Received: 27 November 2013/Accepted: 29 April 2014/Published online: 5 June 2014

(C) The Author(s) 2014. This article is published with open access at Springerlink.com

\begin{abstract}
The coordination polymer $\left[\mathrm{Ti}(\mathrm{OiPr})_{3}(\mathrm{OO}-\right.$ $\mathrm{CCH}_{2} \mathrm{CH}_{2} \mathrm{CH}_{2} \mathrm{C}_{3} \mathrm{~N}_{2} \mathrm{H}_{3}$ ) ] $n$ was prepared from 4-(imidazol1-yl)butyric acid and titanium isopropoxide. The structure of the compound is remarkable, as the carboxylate group is coordinated in a chelating manner and no dimerization of the $\mathrm{Ti}(\mathrm{O} i \mathrm{Pr})_{3}$ groups through OR bridges was observed.
\end{abstract}

Keywords Titanium alkoxides .

Carboxylate derivatives - Coordination polymers .

Structure analysis

\section{Introduction}

The chemistry of titanium alkoxide derivatives with organic co-ligands $[1,2]$ is of topical interest because of the importance of such compounds in sol-gel and CVD processes. Two main types of derivatives are known: (1) adducts of neutral Lewis bases (LB) of the general composition $\mathrm{Ti}(\mathrm{OR})_{4}(\mathrm{LB})$, and (2) derivatives $\mathrm{Ti}(\mathrm{OR})_{4-x}(\mathrm{CL})_{x}$ where one or more OR groups of $\mathrm{Ti}(\mathrm{OR})_{4}$ were substituted by an anionic chelating ligand (CL) and which are prepared by reaction of $\mathrm{Ti}(\mathrm{OR})_{4}$ with $\mathrm{CL}-\mathrm{H}$. The structures of mono-substituted derivatives $\mathrm{Ti}(\mathrm{OR})_{3}(\mathrm{CL})$ with $\beta$-diketonates [3], aminoalcoholates $[4,5], \beta$-aminocarboxylates [6], oximates [7, 8], and others as ligands are related to that of the adducts $\mathrm{Ti}(\mathrm{OR})_{4}(\mathrm{LB})$ with alcohols [9-11] or amines as bases [12-16]. Both types are OR-bridged dimers with octahedrally coordinated titanium atoms. In the derivatives

M. Czakler · M. Puchberger · C. Artner · U. Schubert ( $₫)$

Institute of Materials Chemistry, Vienna University of

Technology, Vienna, Austria

e-mail: uschuber@mail.zserv.tuwien.ac.at
$\mathrm{Ti}(\mathrm{OR})_{3}(\mathrm{CL})$, the neutral ligand and one neighboring $\mathrm{OR}$ group of $\mathrm{Ti}(\mathrm{OR})_{4}(\mathrm{LB})$ are replaced by the chelating ligand CL (Fig. 1).

Reactions of $\mathrm{Ti}(\mathrm{OR})_{4}$ with carboxylic acids are special cases. In the first step, one OR group is substituted by a carboxylate ligand. The few derivatives which were isolated and structurally characterized have either the composition $\left[\mathrm{Ti}(\mathrm{OR})_{3}\left(\mathrm{OOCR}^{\prime}\right)\right]_{2}$, with bridging carboxylate ligands [17], or $\left[\mathrm{Ti}(\mathrm{OR})_{3}\left(\mathrm{OOCR}^{\prime}\right)(\mathrm{ROH})\right]_{2}$, where $\eta_{1^{-}}$ carboxylate ligands are hydrogen-bonded to the coordinated alcohol at the neighboring titanium atom [17, 18]. In most reactions, however, carboxylate-substituted oxo/alkoxo clusters $\mathrm{Ti}_{a} \mathrm{O}_{b}(\mathrm{OR})_{c}\left(\mathrm{OOCR}^{\prime}\right)_{d}$ were obtained $[1,2]$. This is due to ester formation between the alcohol cleaved in the first step and the employed carboxylic acid. The latter reaction produces water which is the source of the oxo ligands in the clusters.

In the light of the known structural chemistry of $\mathrm{Ti}(\mathrm{OR})_{4}$ derivatives, the outcome of the reaction of $\mathrm{Ti}(\mathrm{O} i \mathrm{Pr})_{4}$ with 4-(imidazol-1-yl)butyric acid, which is reported in this article, is surprising, because the obtained coordination polymer has several unexpected features.
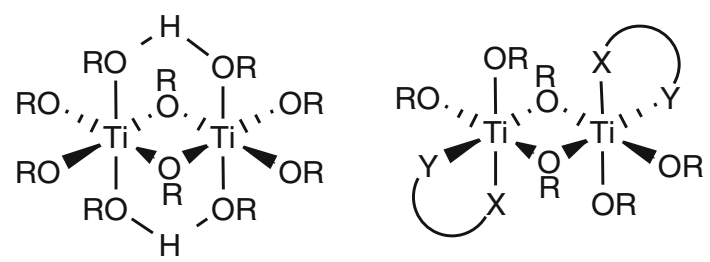

Fig. 1 General structure of the adducts $\operatorname{Ti}(\mathrm{OR})_{4}(\mathrm{LB})$ (left) and the mono-substituted derivatives $\mathrm{Ti}(\mathrm{OR})_{3}(\mathrm{CL})$ (right, $\mathrm{X} \cap \mathrm{Y}=$ chelating ligand) 


\section{Results and discussion}

$\left[\mathrm{Ti}(\mathrm{O} i \mathrm{Pr})_{3}\left(\mathrm{OOCCH}_{2} \mathrm{CH}_{2} \mathrm{CH}_{2} \mathrm{C}_{3} \mathrm{~N}_{2} \mathrm{H}_{3}\right)\right]_{n}$ (1) was obtained by reaction of $\mathrm{Ti}(\mathrm{O} i \mathrm{Pr})_{4}$ with an equimolar amount of 4-(imidazol-1-yl)butyric acid $(\mathrm{L}-\mathrm{H})$ in isopropanol (Scheme 1).

In the crystalline state, compound $\mathbf{1}$ is a coordination polymer with mononuclear $\mathrm{Ti}(\mathrm{O} i \mathrm{Pr})_{3}$ units as connector and $\mathrm{L}$ as linker, coordinating through the carboxylate group to one $\mathrm{Ti}$ atom and the imidazolyl group to the next
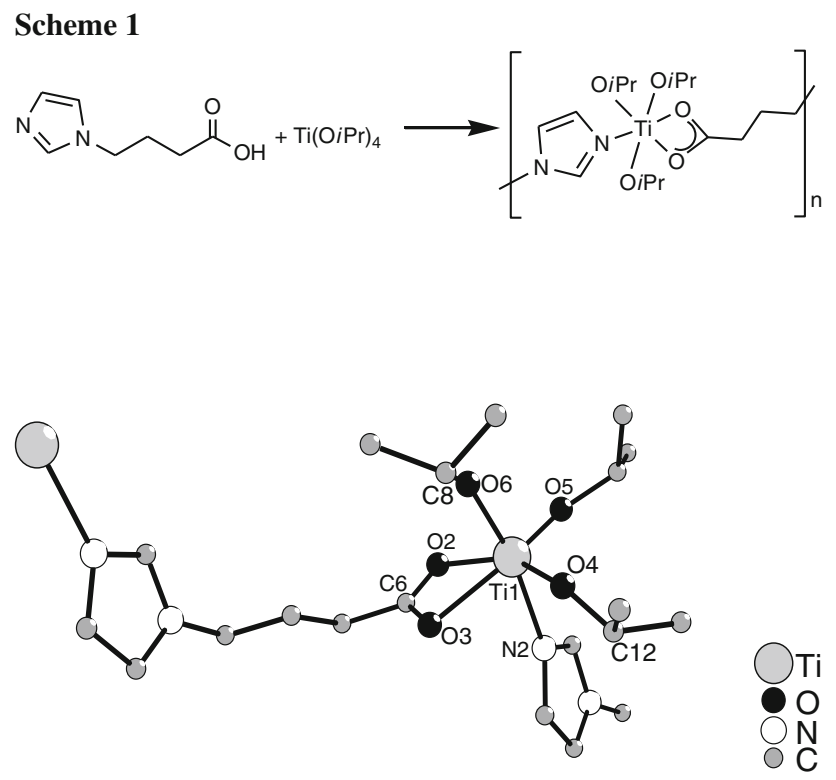

Fig. 2 Ball and stick plot of $\mathbf{1}$. Hydrogen atoms were omitted for clarity. Selected bond lengths/pm and angles $/^{\circ}$ : $\operatorname{Ti}(1)-\mathrm{O}(1)$ 183.42(11), Ti(1)-O(2) 217.34(11), Ti(1)-O(3) 217.82(11), Ti(1)$\mathrm{O}(4)$ 177.80(11), $\mathrm{Ti}(1)-\mathrm{O}(5)$ 181.40(11), Ti(1)-N(2) 223.79(13); $\mathrm{O}(1)-\mathrm{Ti}(1)-\mathrm{O}(4)$ 98.03(5), O(1)-Ti(1)-O(5) 99.55(5), O(4)-Ti(1)$\mathrm{O}(5)$ 108.2(5), N(2)-Ti(1)-O(2) 81.97(4), N(2)-Ti(1)-O(3) 80.56(4), $\mathrm{O}(1)-\mathrm{Ti}(1)-\mathrm{N}(2) 168.91(5)$
(Fig. 2). Although the alkyl chain is highly flexible, no back-biting of one of the imidazolyl nitrogen atoms to the same titanium atom was observed. The polymer chain extends parallel to the $a$-axis (Fig. 3). The titanium atoms are six-coordinate with a distorted octahedral coordination geometry and the $\mathrm{O} i \mathrm{Pr}$ ligands in a mer arrangement. Distortion of the polyhedron is due to the chelating carboxylate group and results in $\mathrm{O}-\mathrm{Ti}-\mathrm{O}$ bond angles of the $\mathrm{O} i \mathrm{Pr}$ ligands between $99.55^{\circ}$ and $108.2^{\circ}$. The coordinating nitrogen atom is slightly tilted towards the carboxylate ligand. The $\mathrm{Ti}(1)-\mathrm{N}(2)$ distance is distinctly shorter than that observed in the $\mathrm{Ti}(\mathrm{OR})_{4}$ (amine) adducts with primary amines, which are typically in the range 129-131 pm, or in $\mathrm{Ti}(\mathrm{OR})_{x}$ derivatives with DHP ligands (226 pm, DHP$\mathrm{H}_{2}=$ 4,6-dihydroxypyrimidine) [19].

The solution ${ }^{1} \mathrm{H}$ NMR spectrum of $\mathbf{1}$ shows one doublet at $1.22 \mathrm{ppm}$ for the terminal $\mathrm{CH}_{3}$ of the OiPr ligands. The signals of the imidazolyl group appear at 6.73, 7.19, and $7.59 \mathrm{ppm}$. To verify the coordination behavior of the imidazolyl group in solution, 2D correlation spectra $\left({ }^{1} \mathrm{H} /{ }^{15} \mathrm{~N}\right.$ HMBC) of $\mathrm{L}-\mathrm{H}$ and the complex were recorded. The spectrum of the complex (Fig. 4) shows correlations at 152 and 224 ppm, while the spectrum of the free ligand shows correlations at 153 and 239 ppm. The shift difference of $15 \mathrm{ppm}$ for one of the two nitrogen atoms is an indication that coordination is retained in solution.

\section{Conclusions}

Reaction of $\mathrm{Ti}(\mathrm{O} i \mathrm{Pr})_{4}$ with 4-(imidazol-1-yl)butyric acid resulted in the formation of the coordination polymer $\left[\mathrm{Ti}(\mathrm{O} i \mathrm{Pr})_{3}\left(\mathrm{OOCCH}_{2} \mathrm{CH}_{2} \mathrm{CH}_{2} \mathrm{C}_{3} \mathrm{~N}_{2} \mathrm{H}_{3}\right)\right]_{n}$ (1). Only few onedimensional titanium-containing coordination polymers were hitherto structurally characterized [20], among them also adducts of $\mathrm{Ti}(\mathrm{OR})_{4}$ with diamines [14-16]. A metal-
Fig. 3 Packing of the chains perpendicular to the $b$-axis. Isopropoxo ligands and hydrogen atoms were omitted for clarity
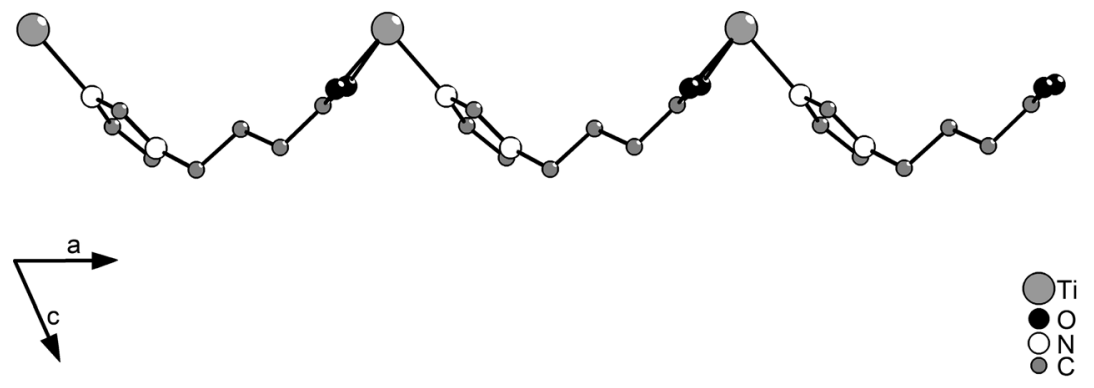

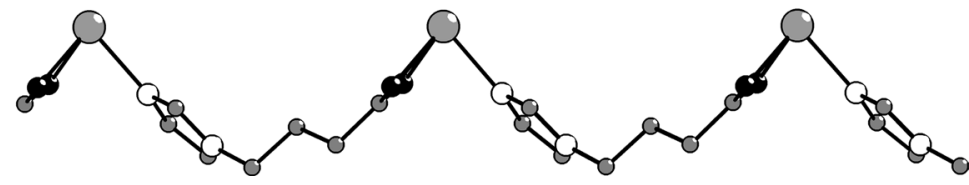




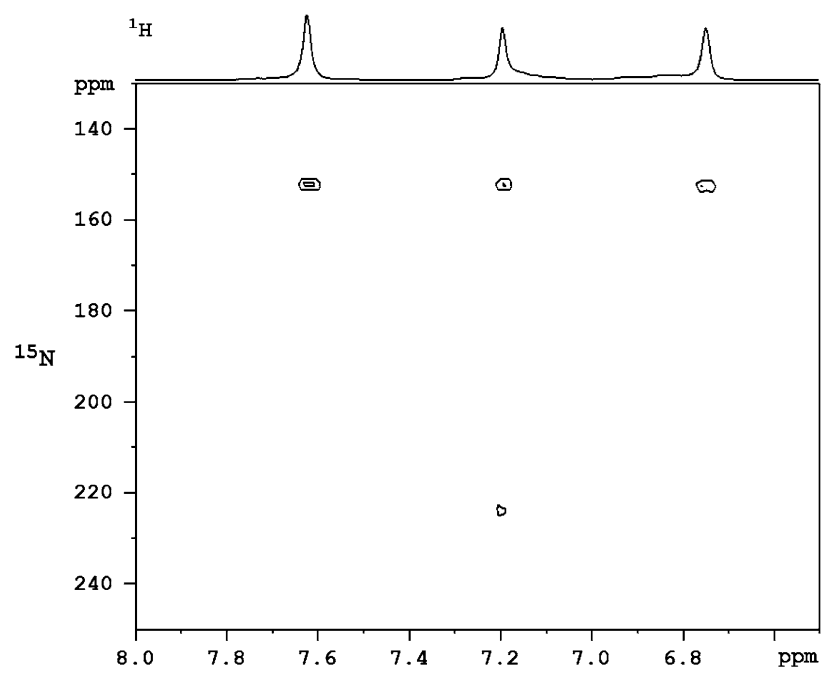

Fig. $4{ }^{1} \mathrm{H} /{ }^{15} \mathrm{~N}$ HMBC NMR spectrum of the complex 1 in $\mathrm{CD}_{2} \mathrm{Cl}_{2}$

organic framework with $\mathrm{Ti}_{8} \mathrm{O}_{8}(\mathrm{OH})_{4}$ units as connector and terephthalate linkers was obtained from $\mathrm{Ti}(\mathrm{O} i \mathrm{Pr})_{4}$ and terephthalic acid [21], and materials at the borderline between sol-gel and metal-organic framework structures in the reaction with tri- and tetracarboxylic acids [22]. On the other hand, amino-substituted carboxylic acids with rigid structures often give rise to the formation of coordination polymers [23].

Apart from the fact that a coordination polymer with $\mathrm{Ti}(\mathrm{OiPr})_{3}$ units was formed, compound 1 shows several remarkable structural features. First, to the best of our knowledge, this is the first titanium alkoxide derivative with a chelating carboxylate group (in all other examples, the carboxylate group bridges two titanium atoms). Second, the fact that coordination of the imidazoyl group inhibits dimerization through alkoxo bridges is quite unusual, because completion of the octahedral coordination sphere of titanium through OR bridges is expected to be more favorable than coordination of a neutral nitrogen donor. A related example is $\left[\mathrm{Ti}\left(\mathrm{OCH}_{2} \mathrm{CMe}_{3}\right)_{3}(\mathrm{py})\right]_{2}(\mu-$ DHP) with very bulky OR ligands [19]. Third, no oxo cluster is formed. The formation of the coordination polymer apparently inhibits ester formation. This was already observed when $\mathrm{Ti}(\mathrm{O} i \mathrm{Pr})_{4}$ was reacted with di-, triand tetracarboxylic acids [21, 22].

\section{Experimental}

All operations were carried out in a moisture- and oxygenfree argon atmosphere using Schlenk techniques. Isopropanol was dried by refluxing twice over sodium metal and distillation. The solvents for NMR spectroscopy (Eurisotop) were degassed prior to use and stored over molecular
Table 1 Crystal data and structure refinement details for $\mathbf{1}$

\begin{tabular}{ll}
\hline Empirical formula & $\mathrm{C}_{16} \mathrm{H}_{30} \mathrm{~N}_{2} \mathrm{O}_{5} \mathrm{Ti}$ \\
Formula weight & 378.32 \\
Crystal system & Triclinic \\
Space group & $P_{\overline{1}}$ \\
$a / \mathrm{pm}$ & $956.79(6)$ \\
$b / \mathrm{pm}$ & $1072.38(6)$ \\
$c / \mathrm{pm}$ & $1121.04(7)$ \\
$\alpha /^{\circ}$ & $85.272(2)$ \\
$\beta /{ }^{\circ}$ & $65.808(3)$ \\
$\gamma /{ }^{\circ}$ & $68.423(2)$ \\
$V / \mathrm{pm}{ }^{3} \times 10^{6}$ & $972.53(10)$ \\
$Z$ & 2 \\
$D_{x} / \mathrm{Mg} \mathrm{m}^{-3}$ & 1.292 \\
$\mu / \mathrm{mm}^{-1}$ & 0.466 \\
Crystal size/mm & \\
No. meas. refl. & $0.2 \times 0.14 \times 0.12$ \\
Obs. refl. $[I>2 \sigma(I)]$ & 20,370 \\
$R_{\text {int }}$ & 4,207 \\
$\theta$ max ${ }^{\circ}$ & 0.0359 \\
$R\left[F^{2}>2 \sigma(F)\right], w R\left(F^{2}\right), S$ & 29.62 \\
No. reflections $/$ parameters & $0.0374,0.0915,1.050$ \\
Weighting scheme & $5298 / 253$ \\
$\delta \rho_{\text {max }}, \delta \rho_{\text {min }} / \mathrm{e} 10^{-6} \mathrm{pm}^{-3}$ & $w=1 /\left[\sigma^{2}\left(F o^{2}\right)+(0.0387 P)^{2}+\right.$ \\
\hline
\end{tabular}

sieve. ${ }^{1} \mathrm{H}$ and ${ }^{13} \mathrm{C}$ solution NMR spectra were recorded on a Bruker AVANCE $250\left(250.13 \mathrm{MHz}\left\{{ }^{1} \mathrm{H}\right\}, 62.86 \mathrm{MHz}\right.$ $\left.\left\{{ }^{13} \mathrm{C}\right\}\right)$. Correlation spectra were recorded on a Bruker AVANCE DPX $300 \quad\left(300.13 \mathrm{MHz} \quad\left\{{ }^{1} \mathrm{H}\right\}, \quad 30.42 \mathrm{MHz}\right.$ $\left.\left\{{ }^{15} \mathrm{~N}\right\}\right)$. Both spectrometers were equipped with a $5-\mathrm{mm}$ inverse-broadband probe head and a z-gradient unit. 2D experiments were measured with Bruker standard pulse sequences: HMBC (Heteronuclear Multiple Bond Correlation). ${ }^{1} \mathrm{H} /{ }^{15} \mathrm{~N}$ HMBC spectra of $\mathbf{1}$ and $\mathrm{L}$ were recorded in $\mathrm{CD}_{2} \mathrm{Cl}_{2}$ and DMSO, respectively.

Titanium tris(isopropoxo) 4-(imidazol-1-yl)butanate (1) $\mathrm{Ti}(\mathrm{O} i \mathrm{Pr})_{4}$ was obtained from ABCR and used as received. $\mathrm{Ti}(\mathrm{O} i \mathrm{Pr})_{4}\left(1.1 \mathrm{~cm}^{3}, 3.8 \mathrm{mmol}\right)$ was added to a solution of $590 \mathrm{mg}$ of 4-(imidazol-1-yl)butyric acid (3.8 mmol) [24] in $3 \mathrm{~cm}^{3}$ of water-free isopropyl alcohol under argon. Crystals of 1 were obtained after 4 weeks (yield $450 \mathrm{mg}$, $31 \%) .{ }^{1} \mathrm{H} \mathrm{NMR}\left(\mathrm{CDCl}_{3}, 250 \mathrm{MHz}\right): \delta=1.21(\mathrm{~d}, 18 \mathrm{H}$, $\left.\mathrm{CH}_{3}\right), 1.83\left(2 \mathrm{H}, \mathrm{CH}_{2}\right), 2.05\left(2 \mathrm{H}, \mathrm{CH}_{2}\right), 3.78\left(2 \mathrm{H}, \mathrm{CH}_{2}\right)$, $4.70\left(3 \mathrm{H}, \mathrm{CH}_{3}\right), 6.74(1 \mathrm{H}, \mathrm{CH}), 7.17(1 \mathrm{H}, \mathrm{CH}), 7.59(1 \mathrm{H}$, $\mathrm{CH}) \mathrm{ppm} ;{ }^{13} \mathrm{C} \mathrm{NMR}\left(\mathrm{CDCl}_{3}, 62.90 \mathrm{MHz}\right): \delta=25.96$ $\left(\mathrm{CH}_{3}\right), 26.69\left(\mathrm{CH}_{2}\right), 32.64\left(\mathrm{CH}_{2}\right), 46.67\left(\mathrm{CH}_{2}\right), 77.36$ $\left(\mathrm{CHMe}_{2}\right), 118.29(\mathrm{CH}), 129.75(\mathrm{CH}), 138.07(\mathrm{CH}), 186.50$ (COO) ppm; IR (ATR): $\bar{v}=3,144$ (vw), 2,963 (w), 2,927 (vw), 2,860 (vw), 1,724 (vvw), 1,591 (m), 1,540 (m), 1,520 
(w), 1,462 (m), 1,443 (w), 1,373 (w), 1,359 (w), 1,327 (w), 1,226 (w), 1,161 (w), 1,118 (s), 1,084 (m), 1,020 (w), 980 (m), 942 (w), 845 (w), 764 (w), 733 (m), 665 (w) cm $\mathrm{cm}^{-1}$; IR $\left(\mathrm{CHCl}_{3}\right): \bar{v}=2,971$ (s), 2,930 (m), 2,864 (w), 1,639 (m), $1,570(\mathrm{~s}), 1,513(\mathrm{w}), 1,441(\mathrm{~m}), 1,376$ (s), 1,283 (w), 1,126 (s), 1,071 (m), 1,042 (w), 1,004 (m), $946(\mathrm{~m}), 911(\mathrm{w}), 888$ (w), $853(\mathrm{w}) \mathrm{cm}^{-1}$.

\section{$X$-ray structure analysis}

All measurements were performed using $\mathrm{MoK}_{\alpha}$ radiation $(\lambda=71.073 \mathrm{pm})$. Data were collected on a Bruker AXS SMART APEX II four-circle diffractometer with $\kappa$-geometry at $100 \mathrm{~K}$ with $\varphi$ and $\omega$-scans and $0.5^{\circ}$ frame width (Table 1). The data were corrected for polarization and Lorentz effects, and an empirical absorption correction (SADABS) was applied. The cell dimensions were refined with all unique reflections. SAINT PLUS software (Bruker Analytical X-ray Instruments, 2007) was used to integrate the frames. Symmetry was checked with the program PLATON.

The structure was solved by the Patterson method (SHELXS97). Refinement was performed by the fullmatrix least-squares method based on $F^{2}$ (SHELXL97) with anisotropic thermal parameters for all non-hydrogen atoms. Hydrogen atoms were inserted in calculated positions and refined riding with the corresponding atom. The carbon atoms of one $\mathrm{O} i \mathrm{Pr}$ ligand of 1 were disordered. Their two positions were refined with about 40 and $60 \%$ occupancy.

CCDC-965819 contains the supplementary crystallographic data for 1 . These data can be obtained free of charge from The Cambridge Crystallographic Data Centre via www.ccdc.cam.ac.uk/data_request/cif.

Acknowledgments This work was supported by the Fonds zur Förderung der wissenschaftlichen Forschung (FWF), Austria (Project P22536). The X-Ray measurements were carried out at the X-Ray Center of the Vienna University of Technology.

Open Access This article is distributed under the terms of the Creative Commons Attribution License which permits any use, distribution, and reproduction in any medium, provided the original author(s) and the source are credited.

\section{References}

1. Schubert U (2005) J Mater Chem 15:3701

2. Schubert U (2007) Acc Chem Res 40:730

3. Errington RJ, Ridland J, Clegg W, Coxall RA, Sherwood JM (1998) Polyhedron 17:659

4. Fric H, Kogler FR, Puchberger M, Schubert U (2004) Z Naturforsch B 59:1241

5. Fric H, Puchberger M, Schubert U (2008) Eur J Inorg Chem 1452

6. Schubert U, Tewinkel S, Möller F (1995) Inorg Chem 34:995

7. Baumann SO, Bendova M, Fric H, Puchberger M, Visinescu C, Schubert U (2009) Eur J Inorg Chem 3333

8. Baumann SO, Bendova M, Puchberger M, Schubert U (2011) Eur J Inorg Chem 573

9. Svetich GW, Voge AA (1972) Acta Crystallogr B 28:1760

10. Fisher J, Van DerSluys WG, Huffman JC, Sears J (1993) Synth React Inorg Metal-Org Chem 23:479

11. Campbell C, Bott SG, Larsen R, Van Der Sluys WG (1994) Inorg Chem 33:4950

12. Fric H, Schubert U (2005) New J Chem 29:232

13. Casarin M, Vittadini A, Schubert U (2007) Monatsh Chem 138:1217

14. Fric H, Puchberger M, Schubert U (2007) Eur J Inorg Chem 376

15. Fric H, Puchberger M, Schubert U (2006) J Sol-Gel Sci Technol 40:155

16. Baumann SO, Du VA, Artner C, Maurer C, Schubert U (2012) Monatsh Chem 143:1637

17. Boyle TJ, Tyner RP, Alam TM, Scott BL, Ziller JW, Potter BG (1999) J Am Chem Soc 121:12104

18. Czakler M, Artner C, Schubert U (2012) Eur J Inorg Chem 3485

19. Boyle TJ, Rodriguez MA, Alam TM (2003) Dalton Trans 4598

20. Dahl GH, Block BP (1967) Inorg Chem 6:1439

21. Dan-Hardi M, Serre C, Frot T, Rozes L, Maurin G, Sanchez C, Ferey G (2009) J Am Chem Soc 131:10857

22. Maurer C, Baumgartner B, Pabisch S, Akbarzadeh J, Peterlik H, Schubert U (2014) Dalton Trans 43:950

23. Constable EC (2012) Coordination polymers. Wiley, New York

24. Alekseenko AL, Popkov SV (2007) Chem Heterocycl Comp 43:769 